\title{
Morphology and ecology of Achnanthidium caravelense (Bacillariophyceae), a new species from Portuguese rivers
}

\author{
Maria Helena Novais ${ }^{* 1,2}$, Daša Hlúbiková ${ }^{1}$, Manuela Morais ${ }^{2}$, Lucien \\ HOFFMANN ${ }^{1} \&$ LUC ECTOR ${ }^{1}$ \\ ${ }^{1}$ Public Research Centre - Gabriel Lippmann, Department of Environment and Agro- \\ Biotechnologies, Belvaux, Luxembourg \\ ${ }^{2}$ Laboratório da Água, Universsidade de Évora, Évora, Portugal \\ With 81 figures and 4 tables
}

Abstract: A new benthic freshwater diatom species belonging to the genus Achnanthidium KüTz. has been recorded from several watercourses in the North of Portugal. Achnanthidium caravelense NovaIs et ECTOR is described as anew species based on light and scanning electron microscopic observations, as well as on its ecological preferences as reconstructed from field observations. The most characteristic morphological features of this species are the different outline of the raphe valve (narrowly elliptic with linear margins) and the rapheless valve (narrowly elliptic to narrowly rhombic with moderately convex margins), the non-protracted broadly rounded apices and the length/widthratio, Furthermore, the areolae of the single row along the mantle are elongated and are morelor less widely open, which is a characteristic discernible in girdle view under light microscopy. The species that $A$. caravelense resembles most is $A$. eutrophilum (LANGE-BERT.) LANGE-BerT.; nevertheless it can be distinguished from the latter by the different raphe valve outline, its higher valve length/width ratio and autecology. A. caravelense is common and abundant in soft waters with low to moderate nutrient content in the North of Portugal.

Key words: Achnanthidium caravelense, Achnanthidium eutrophilum, Bacillariophyceae, diatoms, ecology, morphology, new species, Portugal, ultrastructure.

*Corresponding author 


\section{Introduction}

Species of the genus Achnanthidium KüTz. are common and abundant in benthic communities, colonizing distinct substrates in diverse freshwater habitats (e.g. Potapova \& Ponader 2004, Wojtal et al. 2010).

Achnanthidium has been restituted to genus rank by MANn (Round et al. 1990), since previously it was considered as a subgenus of Achnanthes BORY (e.g. PATRICK \& ReImer 1966). Since then, the genus Achnanthes has been split into several genera, the genus Achnanthidium being confined by Round \& BukntiYarova (1996) to the taxa morphologically similar to the generitype A. microcephalum Kütz. According to Round \& BukhtiYarova (1996), the genus Achnanthidium can therefore be characterized by its linear-lanceolate to lanceolate-elliptic valves, radial or almost transverse striae, which are uniseriate in SEM and coarser in the centre (especially in the raphe valve); cells in girdle view are shallow-V-shaped, the raphe valve presents a fine central raphe hardly expanded at the centre, straight or turned to one side at the apex and a row of slightly elongated areolae in the mantle.

Achnanthidium minutissimum sensu lato is one of the most frequent species within this genus and has been reported from acidic to alkaline and from oligotrophic to hypereutrophic waters, which has been questioned by several researchers and is considered a good example of a common species that needs further studies (Round 2004). Although the A. minutissimum complex has been recently a subject of more detailed studies (e.g. Potapova \& Hamilton 2007), there are still gaps in the knowledge, especially of the ecological preferences of the species. Round (2004) pointed out that the current taxonomie system on diatoms often uses "aggregate" species, which comprise numerous form with different ecological requirements.

During a survey of benthic diatoms sampled in watercourses from Mainland Portugal Achnanthidium frustules morphologically ascribable to the A. minutissimum complex and most similar to A. eutrophilum (Lange-Bert.) Lange-Bert. have been found. Since these individuals were present in numerous reference sites, a more detailed examination of the taxon was performed by means of light (LM) and scanning electron microscopy (SEM). Furthermore, the examination of the environmental characteristics of the sites where it has been sampled allowed us to gather sufficient information to propose this as a new species for science, being described and characterized hereby.

\section{Material and methods}

Benthic diatoms were sampled in spring and summer 2006 and 2007 in streams and rivers from Mainland Portugal. Epilithic diatom samples were treated by oxidation using hot hydrogen peroxide $(35 \%)$ and diluted $\mathrm{HCl}(37 \%)$ in order to 
obtain a suspension of clean frustules. Permanent slides were mounted with Naphrax ${ }^{\circledR}$. LM observations and morphometric measurements were performed using a Leica ${ }^{\circledR}$ DMRX brightfield microscope with 100x oil immersion objective and light microscopy photographs were taken with a Leica ${ }^{\circledR}$ DC500 camera. Samples selected for scanning electron microscopy analysis were filtrated through polycarbonate membrane filters with a pore diameter of $3 \mu \mathrm{m}$, mounted on stubs using double sided carbon tape and sputtered with platinum $(30 \mathrm{~nm})$ with Modular High Vacuum Coating System (BAL-TEC MED 020) and studied with a Hitachi SU-70, operated at $5.0 \mathrm{kV}$.

Morphological terminology follows Ross et al. (1979), Round et al. (1990) and Krammer \& Lange-Bertalot (1991). For comparison, the following publications were consulted: Cholnoky (1957), Carter \& Denny (1982), Kobayasi \& Mayama (1982), Lange-Bertalot \& Krammer (1989), Krammer \& Lange-Bertalot (1991), Kobayasi (1997), Monnier et al. (2004, 2007), Potapova \& Ponader (2004), Ivanov \& Ector (2006), Potapova (2006), Bukhtiyarova (2007), Ponader \& Potapova (2007), Potapoya \& Hamilton (2007), Taylor et al. (2007), Morales et al. (2009), Zidarova et al. (2009), Hlúbiková et al. (2011), VAn de Vijver et al. (2011a) and VAN DE ViJver etal. (2011b).

To perform the morphometric analysis a total of 120 valves (60 raphe valves and 60 rapheless valves) of each species have been measured under the LM microscope with the 100x oil immersion ofjective.

Ecological preferences of Achnanthidiam caravelense and A. eutrophilum were inferred based on environmental variables from 73 sites from Mainland Portugal where these taxa have been found with arelative abundance above $1 \%$ (31 sites for $A$. caravelense and 43 sites for $A$. eutrophilum). In total 20 environmental parameters were assessed by calculating the abundance weighted-average (WA): $\mathrm{N}_{-\mathrm{NH}_{4}}^{+}\left(\mu \mathrm{g} \mathrm{N}-\mathrm{NH}_{4}^{+} \mathrm{L}^{-1}\right), \mathrm{Cl}^{-}\left(\mathrm{mg} \mathrm{Cl}^{-} \mathrm{L}^{-1}\right)$, total organic carbon TOC $\left(\mathrm{mg} \mathrm{O}_{2}\right.$ $\left.\mathrm{L}^{-1}\right)$, total hardness $\left(\mathrm{mg} \mathrm{CaCO}_{3} \mathrm{~L}^{-1}\right), \mathrm{P}_{-} \mathrm{PO}_{4}{ }^{3-}\left(\mu \mathrm{g} \mathrm{P}^{-} \mathrm{PO}_{4}{ }^{3-} \mathrm{L}^{-1}\right)$, total phosphorus ( $\mu \mathrm{g}$ $\left.\mathrm{P} \mathrm{L}^{-1}\right)$, soluble reactive phosphorus $(\mathrm{SRP})\left(\mu \mathrm{g} \mathrm{P} \mathrm{L}^{-1}\right), \mathrm{N}_{-} \mathrm{NO}_{3}^{-}\left(\mu \mathrm{g} \mathrm{N}-\mathrm{NO}_{3}{ }^{-} \mathrm{L}^{-1}\right)$, $\mathrm{N}-\mathrm{NO}_{2}^{-}\left(\mu \mathrm{g} \mathrm{N}-\mathrm{NO}_{2}^{-} \mathrm{L}^{-1}\right), \mathrm{Na}^{+}\left(\mathrm{mg} \mathrm{Na}^{+} \mathrm{L}^{-1}\right), \mathrm{SO}_{4}{ }^{2-}\left(\mathrm{mg} \mathrm{SO}_{4}{ }^{2-} \mathrm{L}^{-1}\right), \mathrm{Ca}^{2+}\left(\mathrm{mg} \mathrm{Ca}^{2+} \mathrm{L}^{-1}\right)$, DO (\% sat.), DO ( $\left.\mathrm{mg} \mathrm{L}^{-1}\right), \mathrm{pH}$, conductivity $\left(\mu \mathrm{S} \mathrm{cm}^{-1}\right)$, current velocity $\left(\mathrm{m} \mathrm{s}^{-1}\right)$, altitude $(\mathrm{m})$, catchment area $\left(\mathrm{km}^{2}\right)$ and distance from source $(\mathrm{m})$. Standard methods for water chemical analysis were used according to APHA (1995).

The distribution map of Achnanthidium caravelense was generated using GIS software ArcGIS 9.3 (ESRI 2008). Statistical analysis for $A$. caravelense and $A$. eutrophilum morphometric data was performed by analysis of variance over the length/width ratio. Differences in ecological preferences were analysed using only samples from streams (31 sites for A. caravelense and 30 sites for $A$. eutrophilum) since $A$. caravelense was not present in reservoirs. The analysis was performed using a weighted general multivariate model after variables normalization (natural logarithm). Statistical analyses were performed with SPSS software (SPSS 16.0 for windows, SPSS Inc. 1989-2007) and the graphical analysis was performed with the SigmaPlot ${ }^{\circledR}$ software v. 7.101 (SPSS INC. 2001). 


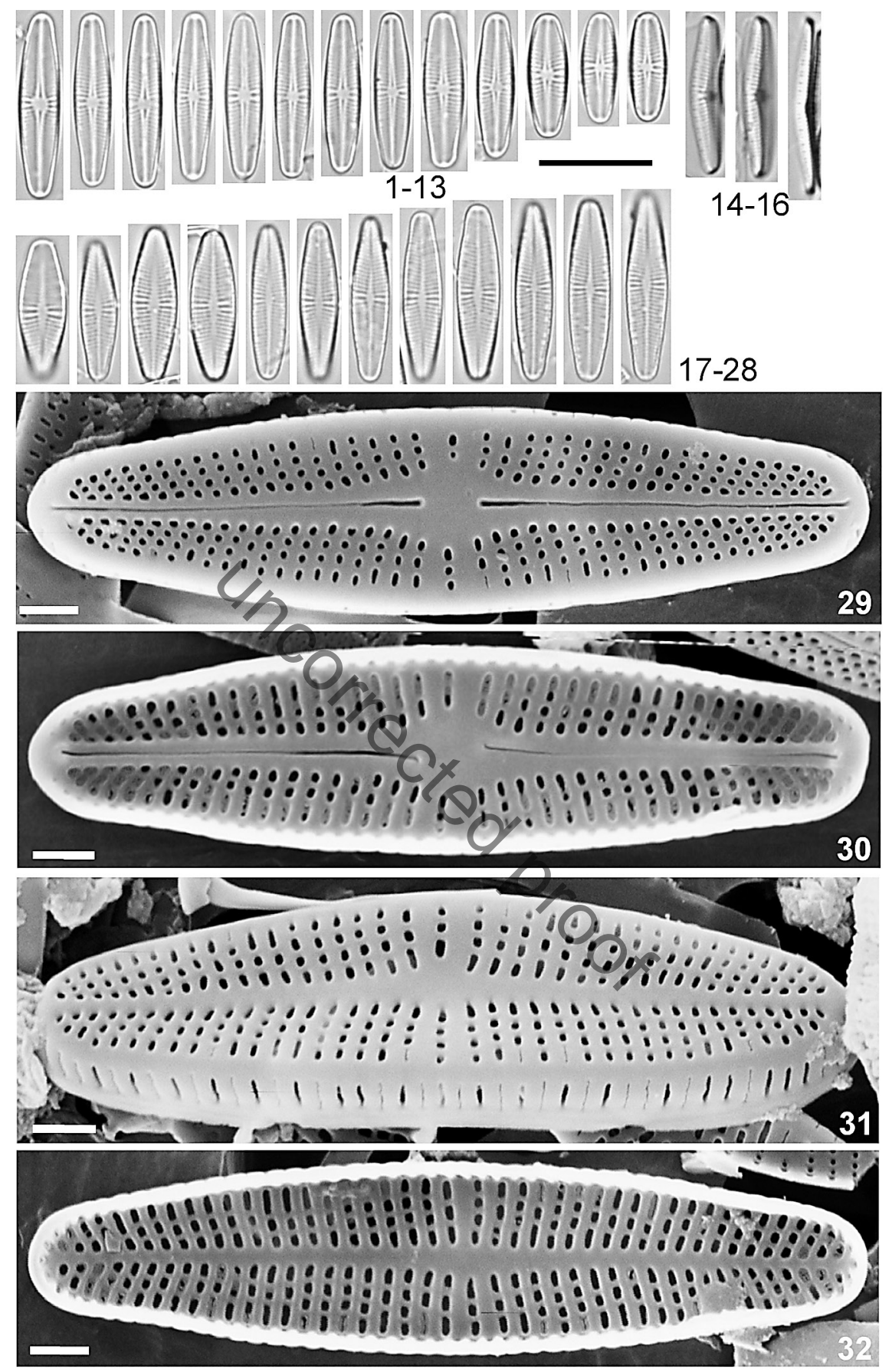

Figs 1-32. Achnanthidium caravelense Novais et Ector. Light and scanning electron micrographs of the type population from Caravelas stream (Portugal). 1-13. LM views of raphe valves. 14-16. LM views of frustules in girdle view. 17-28. LM views of rapheless valves. 29. SEM external view of a raphe valve. 30. SEM internal view of a raphe valve. 31. SEM external view of a rapheless valve. 32. SEM internal view of a rapheless valve. Scale bar (Figs $1-28)=10 \mu \mathrm{m}$; scale bars (Figs 29-32) $=1 \mu \mathrm{m}$. 

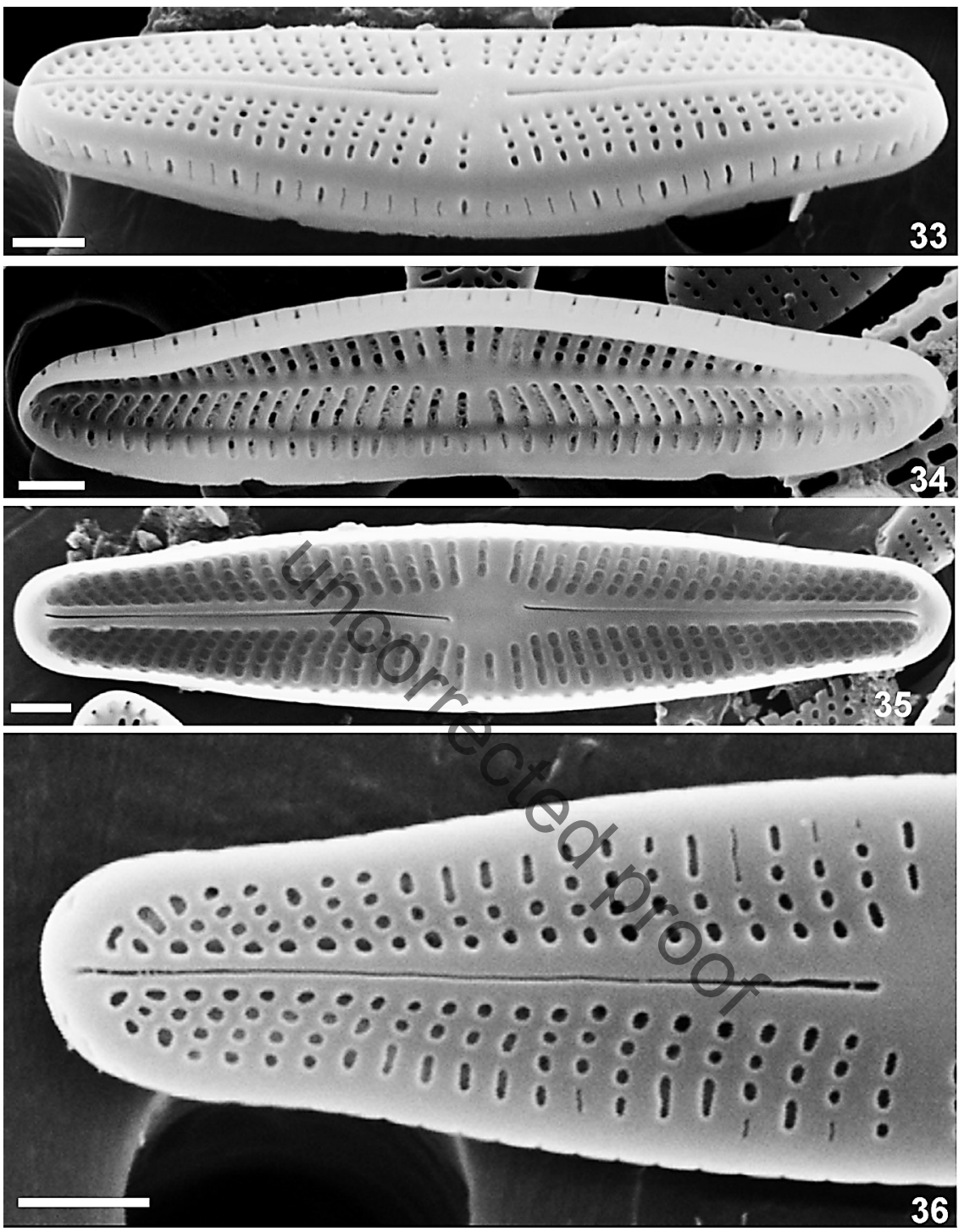

Figs 33-36. Achnanthidium caravelense Novais et EстоR. Scanning electron micrographs of the type population from Caravelas stream (Portugal). 33. SEM external girdle view of a raphe valve showing the row of areolae more or less enlarged in the mantle. 34. SEM internal oblique view of a raphe valve showing the row of areolae more or less enlarged in the mantle. 35. SEM internal valve view of a raphe valve showing the areolae covered by hymens. 36. SEM detail of the apical area of a raphe valve showing the slit-like areolae in the margins, in external view. Scale bars (Figs 33-36) $=1 \mu \mathrm{m}$. 
136 Novals ET AL.
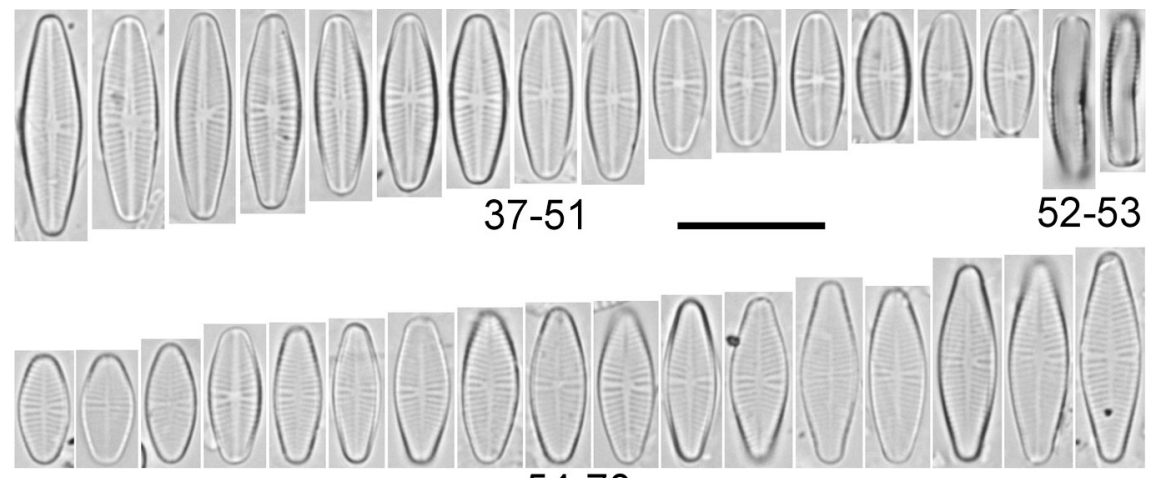

54-70
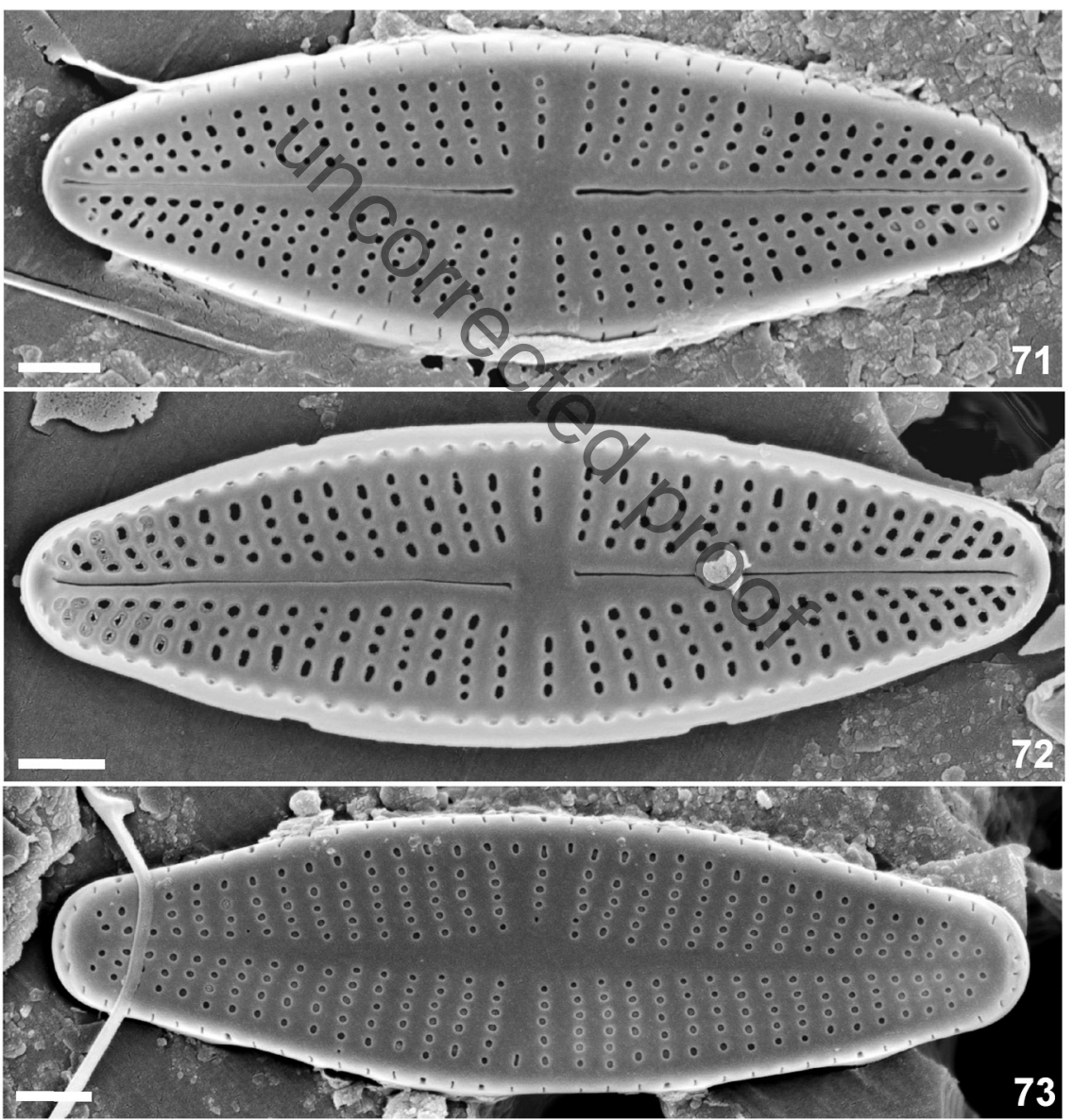

Figs 37-73. Achnanthidium eutrophilum (Lange-Bert.) Lange-Bert. Light and scanning electron micrographs of the population from Monte Novo Reservoir (Portugal). 37-51. LM views of raphe valves. 52, 53. LM views of frustules in girdle view. 54-70. LM views of rapheless valves. 71. SEM external view of a raphe valve. 72. SEM internal view of a raphe valve. 73. SEM external view of a rapheless valve. Scale bar (Figs 37-70) $=10 \mu \mathrm{m}$; scale bars (Figs 71-73) $=1 \mu \mathrm{m}$. 

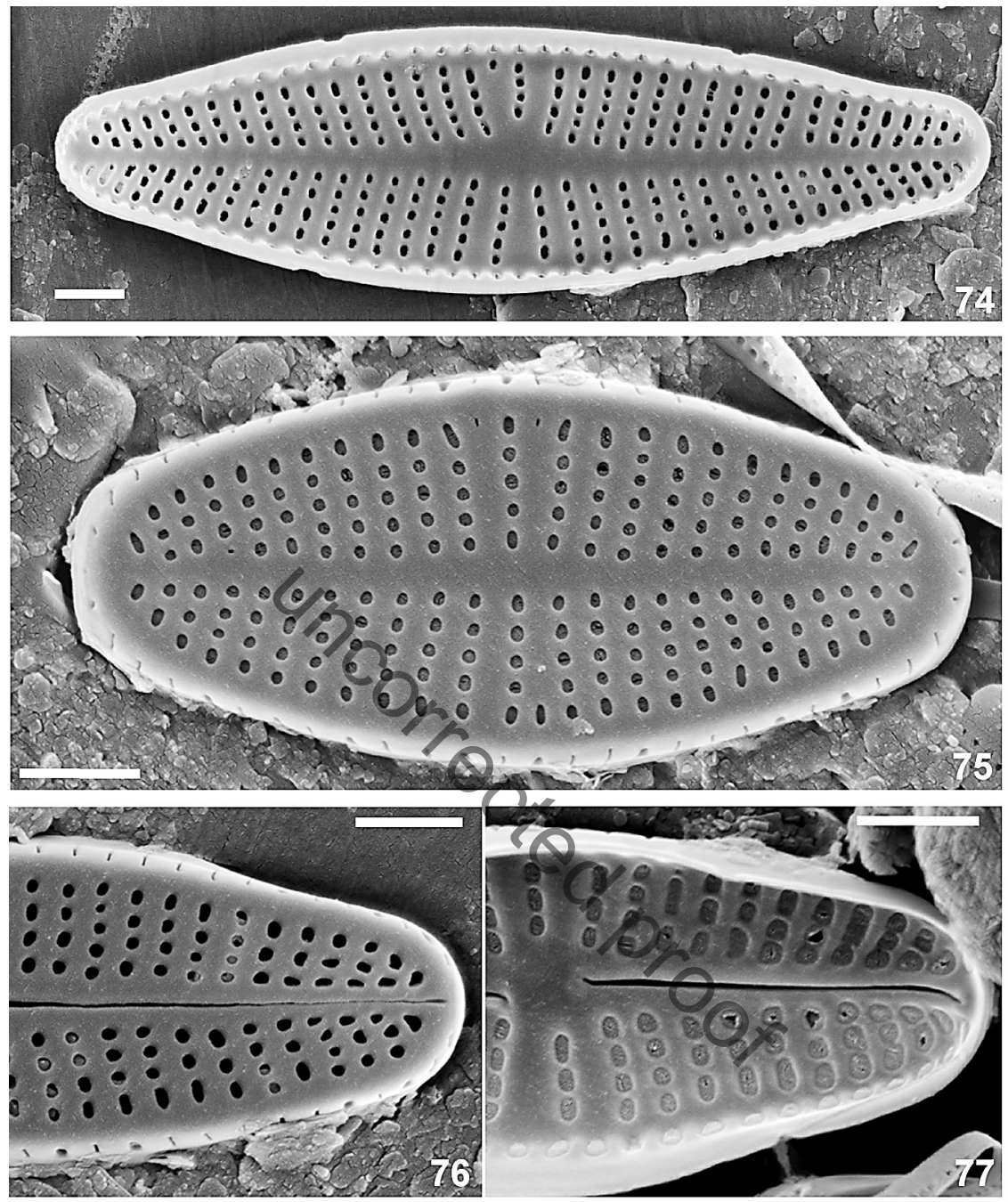

Figs 74-77. Achnanthidium eutrophilum (Lange-Bert.) LANGE-Bert. Scanning electron micrographs of the population from Monte Novo Reservoir (Portugal). 74. SEM internal view of a rapheless valve. 75. SEM external view of a raphe valve showing the row of areolae more or less enlarged in the mantle. 76. SEM detail of the apical area of a raphe valve in external view. 77. SEM detail of the apical area of a raphe valve in internal view. Scale bars $($ Figs $74-77)=1 \mu \mathrm{m}$. 
138 Novals ET AL.

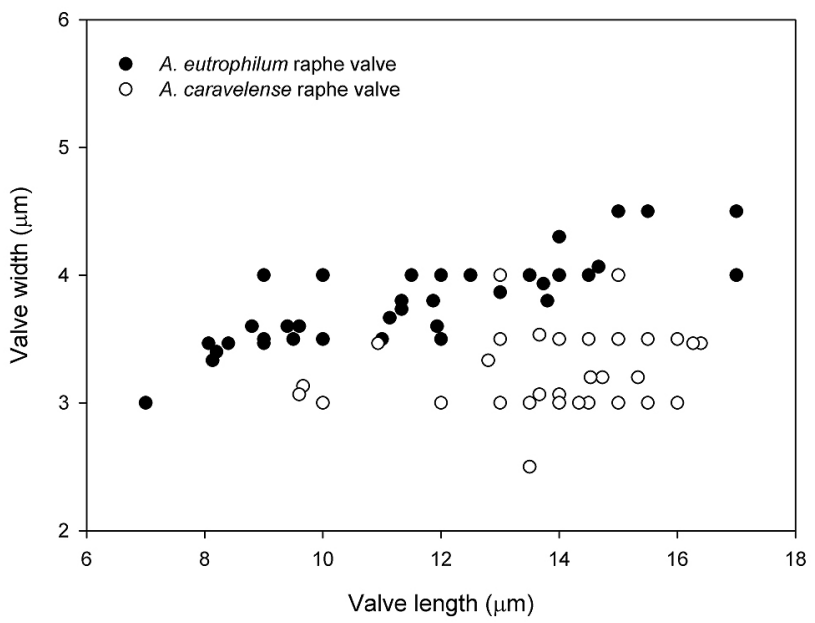

Fig. 78. Dimensions of raphe valves of Achnanthidium caravelense (Caravelas stream) and A. eutrophilum (Monte Noyo Reservoir) $(\mathrm{n}=120)$.

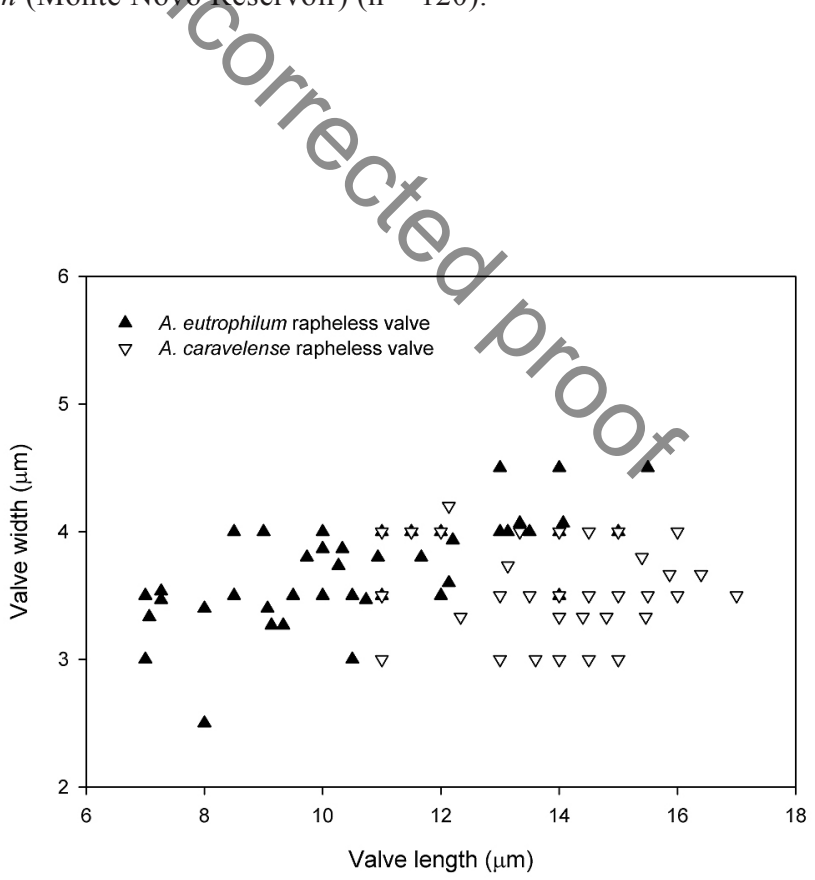

Fig. 79. Dimensions of rapheless valves of Achnanthidium caravelense (Caravelas stream) and A. eutrophilum (Monte Novo Reservoir) $(\mathrm{n}=120)$. 


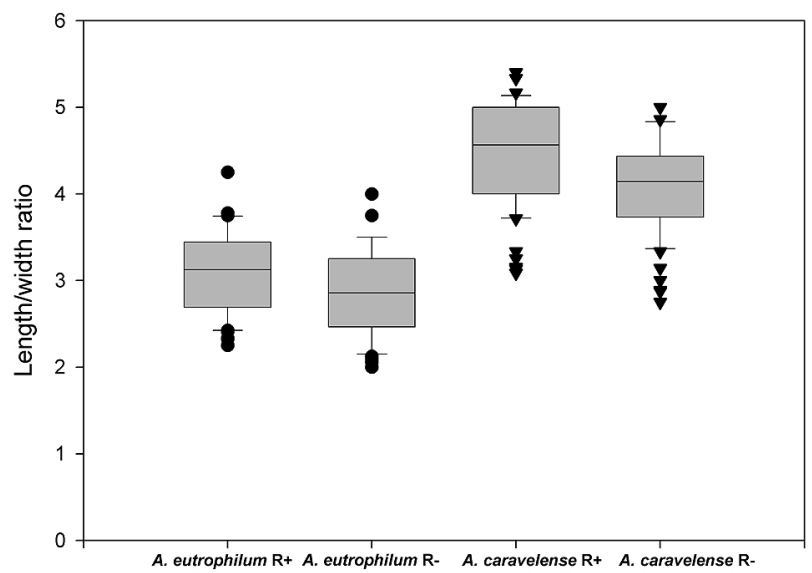

Fig. 80. Length/width ratio of raphe $(\mathrm{R}+)$ and rapheless valves $(\mathrm{R}-)$ of Achnanthidium caravelense (Caravelas strean) and A. eutrophilum (Monte Novo Reservoir) $(\mathrm{n}=240)$.
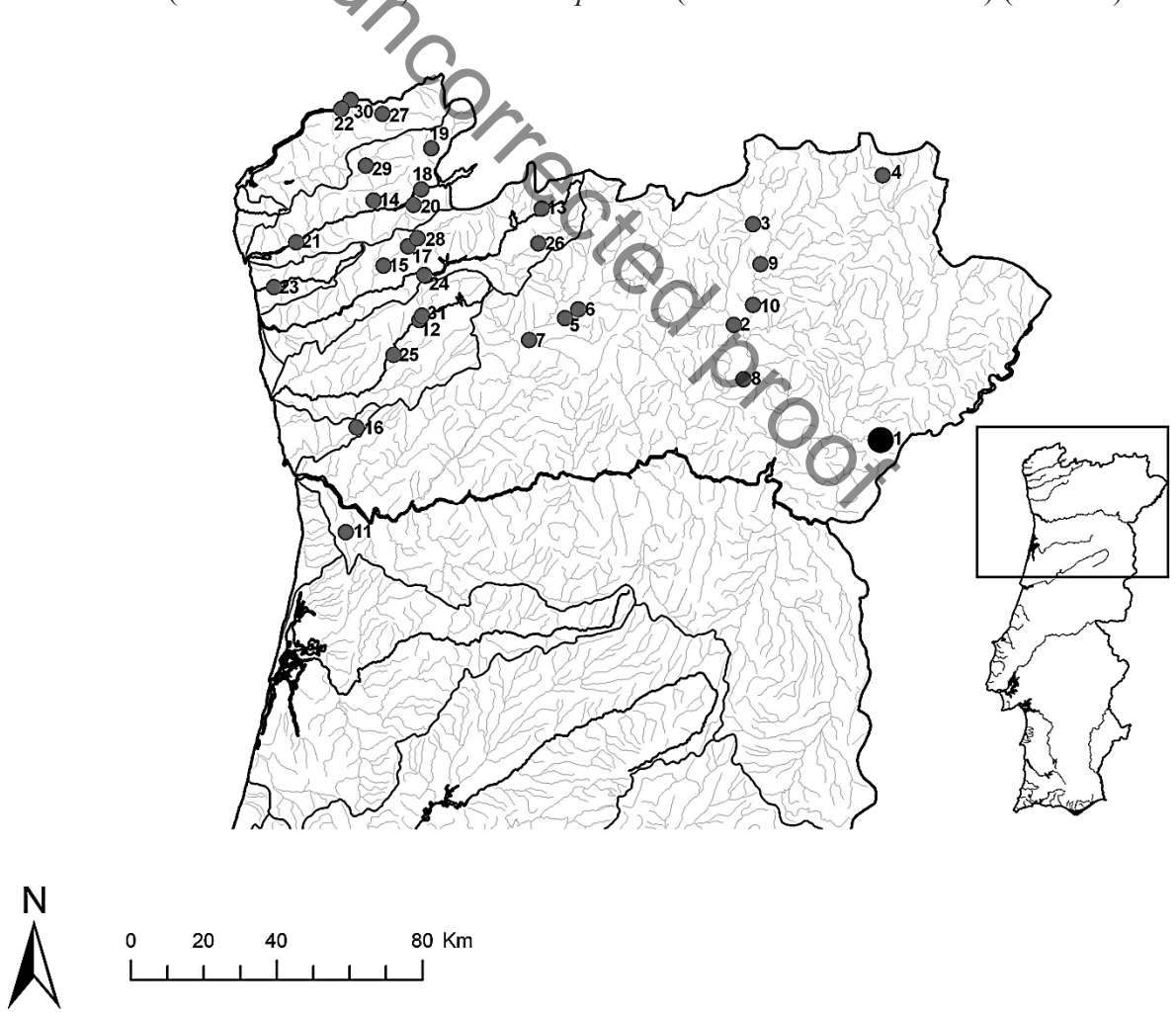

Fig. 81. Distribution map of Achnanthidium caravelense in the North and Centre of Portugal. The black circle represents the type locality. The numbers correspond to the identification number (ID) presented in Table 4. 
Table 1. Comparison between Achnanthidium caravelense and morphologically similar species.

\begin{tabular}{|c|c|c|c|}
\hline Achnanthidium & $\begin{array}{l}\text { caravelense } \\
\text { (Caravelas stream, } \\
\text { this study) }\end{array}$ & $\begin{array}{l}\text { affine } \\
\text { (KRAMMER \& } \\
\text { LANGE-BERTALOT } \\
\text { 1991) }\end{array}$ & $\begin{array}{l}\text { eutrophilum } \\
\text { (HLÚBIKOVÁ et } \\
\text { al. 20101, } \\
\text { Germany) }\end{array}$ \\
\hline Valve length $(\mu \mathrm{m})$ & $9.6-17$ & $8-30$ & $7.5-16$ \\
\hline Valve width $(\mu \mathrm{m})$ & $2.5-4.2$ & $3.5-5$ & $3.2-4.8$ \\
\hline \multicolumn{4}{|l|}{ Raphe valve } \\
\hline Valve outline & narrowly elliptic & $\begin{array}{l}\text { rhombic to } \\
\text { rhombic-lanceolate }\end{array}$ & narrowly rhombic \\
\hline Valve apices & $\begin{array}{l}\text { broadly rounded; not } \\
\text { protracted }\end{array}$ & acutely protracted & $\begin{array}{l}\text { bluntly rounded to } \\
\text { broadly cuneate }\end{array}$ \\
\hline Central area & rounded to elliptic & $\begin{array}{l}\text { large wedge-shaped } \\
\text { fascia }\end{array}$ & $\begin{array}{l}\text { small rhombic, } \\
\text { almost absent }\end{array}$ \\
\hline Striae (in $10 \mu \mathrm{m}$ ) & & $22-24$ & $25-30(27)$ \\
\hline Number of areolae & $2-4$ & $3-5$ & $4-6$ \\
\hline Striation pattern & $\begin{array}{l}\text { slightly radiate in the } \\
\text { middle part, strongly } \\
\text { radiate and slightly } \\
\text { more densely spaced } \\
\text { near the apices }\end{array}$ & $\begin{array}{l}\text { slightly more densely } \\
\text { spaced near apices }\end{array}$ & $\begin{array}{l}\text { rounded to elon- } \\
\text { gated areolae }\end{array}$ \\
\hline Areola morphology & $\begin{array}{l}\text { rounded to elongat- } \\
\text { ed; often slit-like } \\
\text { near the valve } \\
\text { margin }\end{array}$ & $\begin{array}{l}\text { areolae rounded near } \\
\text { apices }\end{array}$ & $\begin{array}{l}\text { slit-like or both } \\
\text { slit-like and broadly } \\
\text { elliptic in the } \\
\text { mantle }\end{array}$ \\
\hline \multicolumn{4}{|l|}{ Rapheless valve } \\
\hline Valve outline & narrowly rhombic & $\begin{array}{l}\text { rhombic to } \\
\text { rhombic-lanceolate }\end{array}$ & $\begin{array}{l}\text { narrowly rhomboi- } \\
\text { dal to lanceolate }\end{array}$ \\
\hline Valve apices & $\begin{array}{l}\text { obtusely rounded not } \\
\text { protracted }\end{array}$ & acutely protracted & $\begin{array}{l}\text { bluntly rounded to } \\
\text { broadly cuneate }\end{array}$ \\
\hline Central area & elliptic & asymmetrical & $\begin{array}{l}\text { narrowly rhomboi- } \\
\text { dal to lanceolate, } \\
\text { almost absent }\end{array}$ \\
\hline Striae (in $10 \mu \mathrm{m}$ ) & $30-32$ & $22-24$ & $25-30$ \\
\hline Number of areolae & $3-4$ & $3-4$ & $4-6$ \\
\hline Striation pattern & $\begin{array}{l}\text { slightly radiate in the } \\
\text { middle part, strongly } \\
\text { radiate and slightly } \\
\text { more densely spaced } \\
\text { near the apices }\end{array}$ & $\begin{array}{l}\text { equidistant } \\
\text { throughout }\end{array}$ & $\begin{array}{l}\text { rounded to elon- } \\
\text { gated areolae }\end{array}$ \\
\hline Areola morphology & $\begin{array}{l}\text { rounded to elongat- } \\
\text { ed; often slit-like } \\
\text { near the valve } \\
\text { margin }\end{array}$ & $\begin{array}{l}\text { usually rounded } \\
\text { areolae }\end{array}$ & $\begin{array}{l}\text { slit-like or both } \\
\text { slit-like and broadly } \\
\text { elliptic in the } \\
\text { mantle }\end{array}$ \\
\hline
\end{tabular}




\begin{tabular}{|c|c|c|c|c|}
\hline $\begin{array}{l}\text { eutrophilum } \\
\text { (Monte Novo } \\
\text { Reservoir, Portugal, } \\
\text { this study) }\end{array}$ & $\begin{array}{l}\text { exile } \\
\text { (KRAMMER \& } \\
\text { LANGE-BERTA- } \\
\text { LOT 1991) } \\
\end{array}$ & $\begin{array}{l}\text { minutissimum } \\
\text { (KRAMMER \& } \\
\text { LANGE-BERTA- } \\
\text { LOT 1991) } \\
\end{array}$ & $\begin{array}{l}\text { standeri } \\
\text { (CHOLNOKY } \\
1957)\end{array}$ & $\begin{array}{l}\text { taiaensis } \\
\text { (CARTER \& } \\
\text { DENNY } \\
1982 \text { ) } \\
\end{array}$ \\
\hline $7-17$ & $12-33$ & $5-20(25)$ & $24-38$ & $10-35$ \\
\hline $2.5-4.5$ & $4-6$ & (2.5) $3-3.5(4)$ & $4.5-5.5$ & $3-5$ \\
\hline rhombic to & rhombic-lanceolate & linear-elliptic to & linear to & lanceolate \\
\hline rhombic-elliptic & to linear-lanceolate & linear-lanceolate & linear-lanceolate & \\
\hline $\begin{array}{l}\text { broadly rounded; } \\
\text { not protracted to } \\
\text { slightly protracted }\end{array}$ & $\begin{array}{l}\text { bluntly rounded; not } \\
\text { protracted to } \\
\text { slightly protracted }\end{array}$ & protracted; capitate & $\begin{array}{l}\text { protracted; } \\
\text { rounded }\end{array}$ & rounded \\
\hline very small or absent & elliptic & $\begin{array}{l}\text { irregular; } 1-2 \\
\text { shortened striae }\end{array}$ & $\begin{array}{l}\text { small; sometimes } \\
\text { only in one side }\end{array}$ & small oval \\
\hline $22-26$ & $25-30$ & c. 30 & $28-30$ & $36-40$ \\
\hline $3-5$ & - & $3-4$ & - & - \\
\hline $\begin{array}{l}\text { radiate; slightly } \\
\text { more densely spaced } \\
\text { near the apices }\end{array}$ & $\begin{array}{l}\text { radiate; more } \\
\text { densely spaced near } \\
\text { the apices }\end{array}$ & $\begin{array}{l}\text { slightly more } \\
\text { densely spaced near } \\
\text { theapices }\end{array}$ & $\begin{array}{l}\text { slightly radiate in } \\
\text { the middle; } \\
\text { strongly radiate }\end{array}$ & radiate \\
\hline $\begin{array}{l}\text { rounded to slightly } \\
\text { elongated; some- } \\
\text { times slit-like near } \\
\text { the valve margin }\end{array}$ & - & areolae ror & - & - \\
\hline rhombic & $\begin{array}{l}\text { rhombic-lanceolate } \\
\text { to linear-lanceolate }\end{array}$ & $\begin{array}{l}\text { linear-elliptic to } \\
\text { linear-lanceolate }\end{array}$ & $\begin{array}{l}\text { linearto } \\
\text { linear-lanceolate }\end{array}$ & lanceolate \\
\hline $\begin{array}{l}\text { broadly rounded; } \\
\text { not protracted to } \\
\text { slightly protracted }\end{array}$ & $\begin{array}{l}\text { bluntly rounded; not } \\
\text { protracted to } \\
\text { slightly protracted }\end{array}$ & protracted; capitate & $\begin{array}{l}\text { protracted; } \\
\text { rounded }\end{array}$ & rounded \\
\hline very small or absent & elliptic & elliptic to lanceolate & undefined & small \\
\hline $22-26$ & $25-30$ & c. 30 & $24-26$ & c. 40 \\
\hline $4-6$ & - & $3-5$ & - & - \\
\hline $\begin{array}{l}\text { radiate; slightly } \\
\text { more densely spaced } \\
\text { near the apices }\end{array}$ & $\begin{array}{l}\text { radiate; more } \\
\text { densely spaced near } \\
\text { the apices; more } \\
\text { densely spaced in } \\
\text { the middle than in } \\
\text { the raphe valve }\end{array}$ & $\begin{array}{l}\text { equidistant } \\
\text { throughout }\end{array}$ & $\begin{array}{l}\text { rougher than the } \\
\text { striae of the raphe } \\
\text { valve; short and } \\
\text { thick shadow lines } \\
\text { in the valve edges }\end{array}$ & $\begin{array}{l}\text { perpendicu- } \\
\text { lar to the } \\
\text { midline }\end{array}$ \\
\hline $\begin{array}{l}\text { rounded to slightly } \\
\text { elongated }\end{array}$ & - & $\begin{array}{l}\text { usually rounded } \\
\text { areolae }\end{array}$ & - & - \\
\hline
\end{tabular}




\section{Observations and discussion}

Achnanthidium caravelense Novais et Ector sp. nov.

(Figs 1-36)

Diagnosis: Valvae anguste ellipticae vel anguste rhombicae, linearibus el modice convexis marginibus, leniter vel non protractis late rotundatis apicibus. Longitudo: 9.6-17.0 $\mu \mathrm{m}$, latitudo: $2.5-4.2 \mu \mathrm{m}$. Rhaphovalva concava, area axialis linearis, area centralis fere absens vel rotundata. Rhaphe recta filiformis poris centralibus et extremis terminalibus rectis. Striae transapicales radiantes omnino densiores ad apices, 30 in $10 \mu \mathrm{m}$ vel ad $35-40$ in $10 \mu \mathrm{m}$ ad apices. Striae $2-4$ rotundatis vel transapicaliter elongatis areolis compositae. Areolae nonnunquam rimiformes ad marginem. Striae tantum rotundatis areolis compositae ad apices. Areovalva modice convexa, area axialis angusta linearis modice dilatata ad aream centralem. Area centralis modice elliptica. Striae transapicales radiantes omnino densiores ad apices 30 in $10 \mu \mathrm{m}$ vel 35 in $10 \mu \mathrm{m}$ ad apices. Striae $3-4$ rotundatis vel transapicaliter elongatis areolis compositae. Areolae nonnunquam rimiformes ad marginem. Aperturae internae areolarum occlusae hymenibus. Areolae seriei singularis ad limbum elongatae et nonnunquam late apertae.

Holotype (here designated): BR 4214 (National Botanic Garden, Meise, Belgium), microscopic slide and preserved sample.

Isotypes (here designated): BM-101456 (Natural History Museum, London, UK), ZU7/44 (Hustedt Collection, Bremerhaven, Germany), microscopic slides.

Type locality: Quinta das Quebradas, Caravelas stream (Ribeira das Caravelas), subregion Alto Trás-os-Montes (District:Bragança), in the Parque Natural do Douro Internacional, Portugal (coll. NovAIs, Coll. date 22/07/2007), coordinates $41^{\circ} 13$ ' 55,581" N, $06^{\circ} 45^{\prime} 15,031^{\prime}$ 'W.

Etymology: The specific epithet caravelense refers to the name of the stream "Caravelas" where the type material was sampled (Ribeira das Caravelas).

Description: Valves narrowly elliptic or lanceolate to narrowly rhombic with linear to moderately convex margins and only very weakly to non-protracted, broadly rounded apices. Valve dimensions $(\mathrm{n}=120)$ : 9.6-17.0 $\mu \mathrm{m}$ long and 2.5$4.2 \mu \mathrm{m}$ wide. Raphe valve concave with a linear axial area and a central area varying from almost absent to rounded. Raphe straight, filiform with gradually expanding, straight central raphe pores and straight terminal endings. Transapical striae radiate throughout the entire valve, becoming denser and more strongly radiate towards the apices, 30 in $10 \mu \mathrm{m}$ in the middle of the valve up to 35-40 in 10 $\mu \mathrm{m}$ near the apices. Striae composed of 2-4 rounded to transapically elongated areolae, sometimes being slit-like near the valve margin. Striae near the apices formed only by rounded areolae. Rapheless valve slightly convex with narrow, linear axial area slightly widening towards the central area. Central area weakly elliptical and almost absent, with more widely spaced striae bordering it. Transapical striae radiate throughout the whole valve, slightly denser near the 
apices, 30 in $10 \mu \mathrm{m}$ up to 35 in $10 \mu \mathrm{m}$ near the apices. Striae mainly composed of 3-4 round to transapically elongated areolae. Areolae terminating the striae near the valve margin sometimes slit-like. Internal areolae openings occluded by hymenes (Fig. 35). The areolae of the single row along the mantle are elongated and are more or less widely open, which is a characteristic discernible under LM in girdle view (Figs 14-16).

\section{Comparison with similar species}

Achnanthidium caravelense is one of the few species presenting an irregular appearance of the striae in girdle view, due to some enlarged areolae in the mantle. Among the few species presenting this characteristic we can find the African species Achnanthes standeri CHOLNOKY and A. taiaensis J. R. CARTER, described from South Africa by Cholnoky (1957) and from Sierra Leone by CARTer \& Denny (1982), respectively. Nevertheless, Achnanthidium caravelense differs from Achnanthes standeri by the absence of the clearly visible irregularities in the rapheless valve in valve view (under LM), the more linear to linear-lanceolate rapheless valve in $A$. standeri, its larger valve dimensions and the central area sometimes unilaterally expanded to the valye margin. Achnanthes taiaensis also presents clearly visible irregularities in the striae of the rapheless valve in valve view (under LM) and its striae are perpendicular to the midline, about 40 in $10 \mu \mathrm{m}$, whilst in Achnanthidium caravelense the striae are diways radiant and circa 30 in $10 \mu \mathrm{m}$ up to 35 in $10 \mu \mathrm{m}$ close to the apices. Achnanthes taiaensis and A. standeri are two poorly known species, therefore they should be subject of detailed studies, since the original descriptions and drawings provided by HOLNOKY (1957) and CARTER $_{\text {HOL }}$ \& DENNY (1982) correspond better to the current concept of the genus Achnanthidium and a future transfer to this genus should be considered.

The valves of Achnanthidium caravelense are usually wider than those of $A$. minutissimum, which presents both raphe and rapheless, linear-elliptic to linearlanceolate valves with protracted capitate ends, while $A$. caravelense shows a narrowly rhombic rapheless valve and not protracted rounded ends. Achnanthidium caravelense can be easily distinguished from A. affine (GRun.) CZARn. by the absence of the typical central area presenting a large wedge-shaped fascia. Achnanthidium exile (KüTz.) Round et Buкht. differs from $A$. caravelense by its wider valves and the typical elliptic central area in the raphe valve.

To facilitate the comparison between Achnanthidium caravelense and morphologically similar species, their morphological characteristics are summarized in Table 1.

The species that Achnanthidium caravelense resembles most in terms of valve dimensions and outline is $A$. eutrophilum, which led us to compare the morphology and ultrastructure of $A$. caravelense (Figs 1-36) with a typical population of A. eutrophilum from Portugal (Figs 37-77). The Portuguese population of $A$. eutrophilum corresponds well to the characteristics of the epitype material (HLÚBIKOVÁ 
et al. 2010), just differing by its slightly narrower valves: $2.5-4.5 \mu \mathrm{m}$ for the Portuguese population and 3.2-4.8 $\mu \mathrm{m}$ for the epitype material from the Main River in Germany, as can be seen in Table 1 where both populations are compared.

The observation of the LM micrographs showed that Achnanthidium eutrophilum presents a more rhombic raphe valve than $A$. caravelense; nevertheless, its rapheless valves are quite similar. Therefore, a morphometric analysis was performed in order to verify if there were measurable differences between these two species. A total of 120 valves (60 raphe valves and 60 rapheless valves) of each species have been measured and the results are given in Figures 78 and 79. The morphometric analysis shows that there are differences between the two Achnanthidium species, mainly regarding the raphe valve, which is longer and narrower in A. caravelense than in A. eutrophilum, as seen in Figure 78. The rapheless valves are more similar, presenting more overlap among specimens, even though the majority of the Achnanthidium caravelense valves are larger, while the width is quite similar.

The valve outline (especially of the raphe valve, seen in LM micrographs) and the morphometric analysis in terms of width and length demonstrated differences in both species. This led us to consider that the length/width ratio can be a good character to distinguish between them. The box-plots with the length/width ratio of Achnanthidium caravelense and A. eutrophilum (Fig. 80) showed that it is indeed a good character to distinguish between them, especially in the case of the raphe valve. In addition, analysis of ariance evidenced significant differences between the length/width ratio of Achnanthidium caravelense and A. eutrophilum with $p<0.001$. Achnanthidium caravelense presents a length/width ratio usually above 4 while in A. eutrophilum it is around 3,as seen in Table 2 where the main morphometric characteristics of both species are summarized.

\section{Ecology, distribution and associated diatom flora}

Although the morphology of Achnanthidium caravelense under LM could resemble A. eutrophilum at first sight, the fact that it was found in samples from several reference sites, according to the classification in the context of the implementation of the Water Framework Directive (2000/60/EC) in Portugal, made us consider it could be a species with different ecological requirements. Subsequently, the abundance-weighted averages of 16 physical and chemical variables and current velocity, altitude, distance from source and catchment area were calculated for both species in Portugal (Table 3).

Analysis of the variables weighted averages and their ranges, presented in Table 3, supports the hypothesis that both species differ by their ecological preferences. The results from a multivariate analysis (Hotelling's Trace statistics) confirm the difference $(p<0.001)$. In Table 3 are marked the variables for which the two species showed statistically significant different preferences. Therefore, the ecological preferences of these species are significantly different (with $p<0.001$ ) 
Table 2. Morphometric comparison between Achnanthidium caravelense (Caravelas stream) and A. eutrophilum (Monte Novo Reservoir, Portugal). Minimum, maximum and median values are presented $(n=240)$.

\begin{tabular}{lllll}
\hline & A. caravelense & A. eutrophilum & \\
\hline & Rapheless valve & Raphe valve & Rapheless valve & Raphe valve \\
Length $(\mu \mathrm{m})$ & $11.0-17.0(14.5)$ & $9.6-16.4(14.7)$ & $7.0-15.5(10.7)$ & $7.0-17.0(12.0)$ \\
Width $(\mu \mathrm{m})$ & $3.0-4.2(3.5)$ & $2.5-4.0(3.1)$ & $2.5-4.5(4.0)$ & $3.0-4.5(4.0)$ \\
Ratio (length/width) & $2.8-5.0(4.1)$ & $3.1-5.4(4.6)$ & $2.0-4.0(2.9)$ & $2.3-4.3(3.1)$ \\
\hline
\end{tabular}

Table 3. Abundance-weighted averages (WA), minimum and maximum of 16 physical and chemical variables and curyent velocity, altitude, distance from source and catchment's area corresponding to the ecological spectrum of the presence of Achnanthidium caravelense and A. eutrophilum in Portugal, Asterisks represent the parameters that were significantly different for both species with $p<0.001 * *$ and $\mathrm{p}<0.05^{*}$.

\begin{tabular}{|c|c|c|c|c|c|c|c|c|}
\hline & \multicolumn{4}{|c|}{ A. caravelense } & \multicolumn{4}{|c|}{ A. eutrophilum } \\
\hline & WA & min & $\max$ & $\mathbf{n}$ & WA & $\min$ & $\max$ & $\mathbf{n}$ \\
\hline $\mathrm{N}-\mathrm{NH} 4+\left(\mu \mathrm{g} \mathrm{N}-\mathrm{NH}_{4}^{+} \mathrm{L}^{-1}\right)$ & 36 & 1 & 320 & 28 & 71 & 1 & 670 & 43 \\
\hline $\mathrm{Cl}-\left(\mathrm{mg} \mathrm{Cl}-\mathrm{L}^{-1}\right) * *$ & 11.2 & 3.0 & 85.0 & 31 & 20.9 & 4.0 & 92.8 & 30 \\
\hline $\mathrm{TOC}\left(\mathrm{mg} \mathrm{O}_{2} \mathrm{~L}^{-1}\right) * *$ & 2.0 & 1.2 & 4.2 & & 3.8 & 0.7 & 18.8 & 29 \\
\hline $\begin{array}{l}\text { Total hardness } \\
\left(\mathrm{mg} \mathrm{CaCO}_{3} \mathrm{~L}^{-1}\right) * *\end{array}$ & 19.1 & 5.0 & 44.0 & & 90.1 & 0.1 & 268.0 & 43 \\
\hline $\mathrm{P}^{-} \mathrm{PO}_{4}^{3-}\left(\mu \mathrm{g} \mathrm{P}_{2} \mathrm{O}_{5} \mathrm{~L}^{-1}\right) * *$ & 6 & 1 & 21 & 24 & 78 & 1 & 900 & 40 \\
\hline Total phosphorus ( $\mu \mathrm{g} \mathrm{P} \mathrm{L}^{-1}$ ) & 9 & 1 & 51 & 27 & 144 & 1 & 1120 & 43 \\
\hline $\begin{array}{l}\text { Soluble reactive phosphorus } \\
\text { (SRP) ( } \mu \mathrm{g} \mathrm{P} \mathrm{L}-1) * *\end{array}$ & 2 & 1 & 7 & 22 & 13 & 1 & 44 & 26 \\
\hline $\mathrm{N}-\mathrm{NO}_{3}^{-}\left(\mu \mathrm{g} \mathrm{N}-\mathrm{NO}_{3}^{-} \mathrm{L}^{-1}\right) * *$ & 1707 & 2 & 4210 & 30 & 2470 & 150 & 7600 & 43 \\
\hline $\mathrm{N}-\mathrm{NO}_{2}^{-}\left(\mu \mathrm{g} \mathrm{N}-\mathrm{NO}_{2}^{-} \mathrm{L}^{-1}\right) * *$ & 21 & 1 & 290 & 29 & 71 & 1 & 220 & 38 \\
\hline $\mathrm{Na}^{+}\left(\mathrm{mg} \mathrm{Na}^{+} \mathrm{L}^{-1}\right) * *$ & 8.3 & 0.4 & 39.3 & 31 & 5.5 & 0.7 & 15.8 & 30 \\
\hline $\mathrm{SO}_{4}^{2-}\left(\mathrm{mg} \mathrm{SO}_{4}^{2-} \mathrm{L}^{-1}\right)$ & 4.4 & 0.1 & 20.1 & 31 & 29.5 & 2.2 & 170.6 & 29 \\
\hline $\mathrm{Ca}^{2+}\left(\mathrm{mg} \mathrm{Ca}^{2+} \mathrm{L}^{-1}\right) * *$ & 4.9 & 2.0 & 15.0 & 31 & 19.8 & 2.0 & 110.6 & 30 \\
\hline DO (\% sat.) & 90 & 76 & 100 & 31 & 85 & 66 & 119 & 30 \\
\hline $\mathrm{DO}\left(\mathrm{mg} \mathrm{L}^{-1}\right) *$ & 8.2 & 6.2 & 9.1 & 31 & 9.4 & 5.2 & 12.8 & 43 \\
\hline $\mathrm{pH}$ & 7.1 & 6.2 & 8.1 & 31 & 8.1 & 6.4 & 9.0 & 43 \\
\hline Conductivity $\left(\mu \mathrm{S} \mathrm{cm}^{-1}\right) *$ & 76 & 28 & 307 & 31 & 263 & 35 & 723 & 43 \\
\hline Current velocity $\left(\mathrm{m} \mathrm{s}^{-1}\right)$ & 0.5 & 0.0 & 1.3 & 31 & 0.7 & 0.0 & 1.9 & 29 \\
\hline Altitude $(\mathrm{m}) * *$ & 196 & 5 & 898 & 31 & 78 & 13 & 545 & 30 \\
\hline Catchment area $\left(\mathrm{km}^{2}\right)$ & 1103 & 13 & 15491 & 31 & 7171 & 19 & 122704 & 30 \\
\hline Distance from source $(\mathrm{m})$ & 38911 & 29 & 129546 & 31 & 83974 & 103 & 968460 & 30 \\
\hline
\end{tabular}


146 Novals et AL.

Table 4. Characteristics of sampling sites. Coordinates referred to the datum Lisboa. The identification number (ID) refers to the identification of the sites presented in the distribution map.

\begin{tabular}{|c|c|c|c|c|c|}
\hline Site & Watercourse (Basin) & $\begin{array}{l}\text { Sampling } \\
\text { date }\end{array}$ & Latitude & Longitude & ID \\
\hline Além da Veiga & Ave River (Ave) & $25 / 09 / 2007$ & $41^{\circ} 32^{\prime} 11,089^{\prime \prime} \mathrm{N}$ & $08^{\circ} 15^{\prime} 48,312^{\prime \prime} \mathrm{W}$ & 12 \\
\hline Alto Cávado & $\begin{array}{l}\text { Cávado River } \\
\text { (Cávado) }\end{array}$ & $24 / 09 / 2007$ & $41^{\circ} 48^{\prime} 43,800^{\prime \prime} \mathrm{N}$ & $07^{\circ} 51^{\prime} 41,200^{\prime \prime} \mathrm{W}$ & 13 \\
\hline Arcos de Valdevez & Vez River (Lima) & $21 / 09 / 2007$ & $41^{\circ} 49^{\prime} 54,300^{\prime \prime} \mathrm{N}$ & $08^{\circ} 24^{\prime} 57,800^{\prime \prime} \mathrm{W}$ & 14 \\
\hline Barral & $\begin{array}{l}\text { Homem River } \\
\text { (Cávado) }\end{array}$ & $26 / 09 / 2007$ & $41^{\circ} 40^{\prime} 15,787^{\prime \prime} \mathrm{N}$ & $08^{\circ} 22^{\prime} 58,694^{\prime \prime} \mathrm{W}$ & 15 \\
\hline Cantim & Leça River (Leça) & $16 / 09 / 2007$ & $41^{\circ} 16^{\prime} 13,790^{\prime \prime} \mathrm{N}$ & $08^{\circ} 28^{\prime} 08,375^{\prime \prime} \mathrm{W}$ & 16 \\
\hline Cavacadouro & $\begin{array}{l}\text { Homem River } \\
\text { (Cávado) }\end{array}$ & $26 / 09 / 2007$ & $41^{\circ} 43^{\prime} 07,787^{\prime \prime} \mathrm{N}$ & $08^{\circ} 18^{\prime} 08,708^{\prime \prime} \mathrm{W}$ & 17 \\
\hline Cidadelhe & Lima River (Lima) & $27 / 09 / 2007$ & $41^{\circ} 51^{\prime} 34,687^{\prime \prime} \mathrm{N}$ & $08^{\circ} 15^{\prime} 32,467^{\prime \prime} \mathrm{W}$ & 18 \\
\hline Férrea & Peneda River (Lima) & $20 / 09 / 2007$ & $41^{\circ} 57^{\prime} 41,166^{\prime \prime} \mathrm{N}$ & $08^{\circ} 13^{\prime} 33,703^{\prime \prime} \mathrm{W}$ & 19 \\
\hline Froufe & Froufe Rfiver (Lima) & $27 / 09 / 2007$ & $41^{\circ} 49^{\prime} 15,387^{\prime \prime} \mathrm{N}$ & $08^{\circ} 17^{\prime} 04,012^{\prime \prime} \mathrm{W}$ & 20 \\
\hline Lanheses & Lima River(1)ima) & $21 / 09 / 2007$ & $41^{\circ} 43^{\prime} 39,800^{\prime \prime} \mathrm{N}$ & $08^{\circ} 40^{\prime} 14,500^{\prime \prime} \mathrm{W}$ & 21 \\
\hline Monção & Minho River(Minho) & $20 / 09 / 2007$ & $42^{\circ} 04^{\prime} 49,800^{\prime \prime} \mathrm{N}$ & $08^{\circ} 29^{\prime} 35,600^{\prime \prime} \mathrm{W}$ & 22 \\
\hline Monte Branco & Neiva River (Lima) & $22 / 09 / 2007$ & $41^{\circ} 36^{\prime} 58,886^{\prime \prime} \mathrm{N}$ & $08^{\circ} 44^{\prime} 37,633^{\prime \prime} \mathrm{W}$ & 23 \\
\hline Parada de Bouro & $\begin{array}{l}\text { Cávado River } \\
\text { (Cávado) }\end{array}$ & & $41^{\circ} 38^{\prime} 53,788^{\prime \prime} \mathrm{N}$ & $08^{\circ} 14^{\prime} 54,716^{\prime \prime} \mathrm{W}$ & 24 \\
\hline Ponte na E.N. 103 & $\begin{array}{l}\text { Rabagão River } \\
\text { (Cávado) }\end{array}$ & & $41^{\circ} 43^{\prime} 33,590^{\prime \prime} \mathrm{N}$ & $07^{\circ} 52^{\prime} 21,180^{\prime \prime} \mathrm{W}$ & 26 \\
\hline Pontilhões & Ave River (Ave) & $22 / 09 / 2007$ & $27^{\prime} 02,800^{\prime \prime} \mathrm{N}$ & $08^{\circ} 20^{\prime} 54,000^{\prime \prime} \mathrm{W}$ & 25 \\
\hline $\begin{array}{l}\text { Quinta das } \\
\text { Quebradas }\end{array}$ & $\begin{array}{l}\text { Caravelas Stream } \\
\text { (Douro) }\end{array}$ & $22-07-2007$ & $13^{\prime} 55,581 " \mathrm{~N}$ & $06^{\circ} 45^{\prime} 15,031^{\prime \prime} \mathrm{W}$ & 1 \\
\hline Rabaçal & Rabaçal River (Douro) & $14 / 08 / 2007$ & $41^{\circ} 3118,013^{\prime \prime} \mathrm{N}$ & $07^{\circ} 13^{\prime} 49,497^{\prime \prime} \mathrm{W}$ & 2 \\
\hline Sabor & Sabor River (Douro) & $10 / 08 / 2007$ & $41^{\circ} 53^{\prime} 10,695^{\prime \prime} \mathrm{N}$ & $06^{\circ} 43^{\prime} 57,239^{\prime \prime} \mathrm{W}$ & 4 \\
\hline Segude & Mouro River (Minho) & $20 / 09 / 2007$ & $42^{\circ} 02^{\prime} 44,394^{\prime \prime} \mathrm{N}$ & $08^{\circ} 23^{\prime} 15,807^{\prime \prime} \mathrm{W}$ & 27 \\
\hline Sequeirós & $\begin{array}{l}\text { Homem River } \\
\text { (Cávado) }\end{array}$ & $26 / 09 / 2007$ & $41^{\circ} 44^{\prime} 19,500^{\prime \prime} \mathrm{N}$ & $08^{\circ} 16^{\prime} 13,400^{\prime \prime} \mathrm{W}$ & 28 \\
\hline Sub-Igreja & Vez River (Lima) & $21 / 09 / 2007$ & $41^{\circ} 55^{\prime} 04,285^{\prime \prime} \mathrm{N}$ & $08^{\circ} 26^{\prime} 34,386^{\prime \prime} \mathrm{W}$ & 29 \\
\hline Tâmega 1 & Tâmega River (Douro) & $24 / 09 / 2007$ & $41^{\circ} 32^{\prime} 25,909^{\prime \prime} \mathrm{N}$ & $07^{\circ} 47^{\prime} 09,085^{\prime \prime} \mathrm{W}$ & 5 \\
\hline Tâmega 2 & Tâmega River (Douro) & $24 / 09 / 2007$ & $41^{\circ} 29^{\prime} 12,991^{\prime \prime} \mathrm{N}$ & $07^{\circ} 54^{\prime} 12,934^{\prime \prime} \mathrm{W}$ & 7 \\
\hline Troporiz & $\begin{array}{l}\text { Gadanha River } \\
\text { (Minho) }\end{array}$ & $20 / 09 / 2007$ & $42^{\circ} 03^{\prime} 27,704^{\prime \prime} \mathrm{N}$ & $08^{\circ} 31^{\prime} 28,094^{\prime \prime} \mathrm{W}$ & 30 \\
\hline Tua & Tua River (Douro) & $16 / 08 / 2007$ & $41^{\circ} 23^{\prime} 12,765^{\prime \prime} \mathrm{N}$ & $07^{\circ} 12^{\prime} 03,892^{\prime \prime} \mathrm{W}$ & 8 \\
\hline Tuela 1 & Tuela River (Douro) & $14 / 08 / 2007$ & $41^{\circ} 40^{\prime} 12,568^{\prime \prime} \mathrm{N}$ & $07^{\circ} 08^{\prime} 27,694^{\prime \prime} \mathrm{W}$ & 10 \\
\hline Tuela 2 & Tuela River (Douro) & $11 / 08 / 2007$ & $41^{\circ} 34^{\prime} 12,526^{\prime \prime} \mathrm{N}$ & $07^{\circ} 09^{\prime} 58,814^{\prime \prime} \mathrm{W}$ & 9 \\
\hline Uima & Uima Stream (Douro) & $14 / 08 / 2007$ & $41^{\circ} 00^{\prime} 44,018^{\prime \prime} \mathrm{N}$ & $08^{\circ} 30^{\prime} 11,363^{\prime \prime} \mathrm{W}$ & 11 \\
\hline Vale Armeiro & Rabaçal River (Douro) & $10 / 08 / 2007$ & $41^{\circ} 46^{\prime} 09,905^{\prime \prime} \mathrm{N}$ & $07^{\circ} 09^{\prime} 46,586^{\prime \prime} \mathrm{W}$ & 3 \\
\hline Veral & Tâmega River (Douro) & $21 / 07 / 2007$ & $41^{\circ} 33^{\prime} 45,071^{\prime \prime} \mathrm{N}$ & $07^{\circ} 44^{\prime} 30,135^{\prime \prime} \mathrm{W}$ & 6 \\
\hline Vilela & Pequeno River (Ave) & $25 / 09 / 2007$ & $41^{\circ} 32^{\prime} 51,100^{\prime \prime} \mathrm{N}$ & $08^{\circ} 15^{\prime} 17,400^{\prime \prime} \mathrm{W}$ & 31 \\
\hline
\end{tabular}


for chlorides, total organic carbon, total hardness, phosphates, soluble reactive phosphorus, nitrates, nitrites, sodium, calcium and altitude. In addition, their ecological preferences are different (with $p<0.05$ ) for conductivity and dissolved oxygen. No significant differences were detected for ammonia, total phosphorus, sulphates, catchment area, distance from source, current velocity, $\mathrm{pH}$ and dissolved oxygen ( $\%$ saturation).

Both Achnanthidium species never occurred in the same samples at times. Achnanthidium caravelense occurs in circumneutral waters (WA pH: 7.1), with low conductivity (WA cond.: $76 \mu \mathrm{S} \mathrm{cm}^{-1}$ ) while in Portugal A. eutrophilum prefers slightly alkaline waters (WA pH: 8.1) with moderate conductivity (WA cond.: 263 $\mu \mathrm{S} \mathrm{cm} \mathrm{cm}^{-1}$ ). Furthermore, the range of nutrient concentrations is more ample for Achnanthidium eutrophilum: WA N-NO $-1,707 \mu \mathrm{g} \mathrm{L}^{-1}$ (A. caravelense) $-2,470$ $\mu \mathrm{g} \mathrm{L}^{-1}$ (A. eutrophilum); WA N-NO${ }_{2}^{-:} 21 \mu \mathrm{g} \mathrm{L}^{-1}$ (A. caravelense) $-71 \mu \mathrm{g} \mathrm{L}^{-1}$ (A. eutrophilum), as well as the soluble reactive phosphorus: WA SRP: $2 \mu \mathrm{g} \mathrm{L}^{-1}$ (A. caravelense) $-13 \mu \mathrm{g} \mathrm{L}^{-1}$ (A. eutrophilum). Furthermore, the analysis proves that both species may occurin similar river types but with different degrees of organic contamination.

The ecological preferences of Achnanthidium eutrophilum in Portuguese rivers are in accordance with the Information provided by LANGE-BeRTALOT \& Metzeltin (1996) who stated that this species occurs in oligotrophic to polytrophic waters and by Ponader \& Potapova (2007), who referred that in the Appalachian rivers (United States of America) this species was found in four sites characterized by $\mathrm{pH}$ between $8.1-8.3$, conductivity between $291-583 \mu \mathrm{S} \mathrm{cm}^{-1}$ and a wide range of nutrient concentrations $\left(\mathrm{NO}_{3}^{-}+\mathrm{NO}_{2}^{-}: 700-2,200 \mu \mathrm{g} \mathrm{L}^{-1}\right)$. Regarding phosphate, Achnanthidium eutrophilum was found in the United States of America in sites with a lower range of values $\left(\mathrm{PO}_{4}^{3--}: 10-26 \mathrm{gg} \mathrm{L}^{-1}\right)$ than the Portuguese populations (WA $\mathrm{PO}_{4}^{3-}: 78 \mu \mathrm{g} \mathrm{L}^{-1}$ ).

In total, Achnanthidium caravelense has been recorded with abundances above $1 \%$ in 31 sampling sites (30 in the North, only one in the Centre, and none in the South of Portugal) belonging to the Ave, Cávado, Douro, Lima, Leça and Minho watersheds. The characterization of the sampling sites and the respective distribution map are presented in Table 4 and Figure 81. Achnanthidium eutrophilum has been recorded in abundances above $1 \%$ in 43 sampling sites in streams and reservoirs distributed all over the country and belonging to the watersheds of Ribeiras do Algarve (5 sites), Mira (1 site), Guadiana (6 sites), Tejo (16 sites), Mondego (5 sites), Vouga (4 sites) and Douro (6 sites).

Besides Achnanthidium caravelense, the diatom community was dominated in its type locality by $A$. lineare W. SM. and $A$. rivulare Potapova et Ponader, which are species characteristic of nutrient-poor to moderately nitrogen rich waters (Potapova \& Ponader 2004, Van de Vijver et al. 2011a). A. rivulare is a species characteristic of soft waters and a $\mathrm{pH}$ of approximately 6 (Potapova \& Ponader 2004 ), while $A$. lineare is characteristic of circumneutral to weakly alkaline waters $(\mathrm{pH} 7.0-8.5)$ and very low to moderate specific conductivity, between 23-200 $\mu \mathrm{S} \mathrm{cm} \mathrm{cm}^{-1}$ (VAN DE ViJVer et al. 2011a). 


\section{Conclusion}

The new species Achnanthidium caravelense clearly belongs to the genus Achnanthidium, according to the description of Round \& BukhtiYarova (1996), on the basis of the valve outline, radiate striae, uniseriate (in SEM) and wider spaced striae in the centre of the valve. In girdle view cells are shallow-V-shaped. The raphe valve has a straight central raphe hardly expanding at the centre and a row of elongated areolae in the mantle.

Within the genus Achnanthidium this species belongs to the complex around A. minutissimum, due to its straight terminal raphe fissures, in opposition to the species with terminal raphe fissures clearly deflected, such as A. convergens $(\mathrm{H}$. Kobayasi) H. Kobayasi, A. japonicum (H. Kobayasi) H. Kobayasi, A. latecephalum H. Kobayasi, A. pyrenaicum (Hust.) H. Kobayasi (Kobayasi 1997), $A$. deflexum (Reimer) J. C. Kingston, A. rivulare Potapova et Ponader 2004 (Potapova $\&$ Ponader 2004) and A. zhakovschikovii Potapova (Potapova 2006).

Achnanthidium caravelense is characterized by a set of distinct morphological and ecological features that separate it well from all other similar Achnanthidium species and it is widely distributed in Portuguese rivers. There is therefore a rather high probability that this species also occurs commonly in other European regions, in rivers with suitable conditions and has not yet been recorded due to probable misidentifications with Achnanthidium eutrophilum or $A$. minutissimum.

\section{Acknowledgements}

This project was supported by Fundação para a Ciênciàe a Tecnologia - Portugal (PhD grant SFRH/BD/21625/2005), by the Fonds National de la Recherche du Luxembourg (grant AFR, PHD-09-120) and by the Public Research Centre- Gabriel Lippmann (Luxembourg). We gratefully acknowledge MaUricio Montaño GårĆ́s for statistical advice, Olatz Aizpurua for GIS assistance, Eric Biehler for German translations, Dr. Maria Angélica Oliveira (Universidade Federal de Santa Maria, Brazil) and Dr. Eduardo A. MoRALES (Universidad Católica Boliviana San Pablo, Cochabamba, Bolivia) for kindly revising the manuscript and Dr. Saúl Blanco (University of León, Spain) and Mr. Pierre COMPĖRE (National Botanic Garden of Belgium, Meise) for the Latin translation.

\section{References}

APHA (1995): Standard Methods for the Examination of Water and Wastewater, ed. 19. American Public Health Association, American Water Works Association, and Water Pollution Control Federation, Washington, D.C.

Bukhtiyarova, L. N. (2007): To revision on the genus Achnanthes s. lato (Bacillariophyta). 1. Achnanthes Bory s. str. and Achnanthidium KützING s. str. genera. - Algologia 17: $112-122$ (in Russian).

CArter, J. R. \& Denny, P. (1982): Freshwater algae of Sierra Leone III. Bacillariophyceae: Part (i) Diatoms from the River Jong (Taia) at Njala. - Nova Hedwigia Beih. 73: 281-331. 
Cholnoky, B. J. (1957): Über die Diatomeenflora einiger Gewässer in den MagaliesBergen nahe Rustenburg (Transvaal). - Bot. Not. 110: 325-362.

ESRI (2008): ArcGIS 9.3. Redlands, California, USA. Environmental Science Research Institute 1999-2008.

Hlúbiková, D., Ector, L. \& Hoffmann, L. (2011): Examination of the type material of some diatom species related to Achnanthidium minutissimum (KüTZING) CzARNECKI (Bacillariophyceae). - Algological Studies 136: xxx-xxx.

Ivanov, P. \& Ector, L. (2006): Achnanthidium temniskovae sp. nov., a new diatom from the Mesta River, Bulgaria. - In: Ognjanova-Rumenova, N. \& Manoylov, K. (Eds): Advances in Phycological Studies, Festschrift in Honour of Prof. Dobrina Temniskova-Topalova, 147-154. Pensoft Publisher \& University Publishing House, Sofia-Moscow.

Kobayasi, H. (1997): Comparative studies among four linear-lanceolate Achnanthidium species (Bacillariophyceae) with curved terminal raphe endings. - Nova Hedwigia 65: 147-163.

Kobayasi, H. \& Mayama, S. (1982): Most pollution-tolerant diatoms of severely polluted rivers in the vicinity of Tokyo. - Jap. J. Phycol. (Sôrui) 30: 188-196.

Krammer, K. \& Lange-Bertalot, H. (1991): Bacillariophyceae 4. Teil: Achnanthaceae. Kritische Ergänzungen zu Navicula (Lineolatae) und Gomphonema. Gesamtliteraturverzeichnis Teil 1-4, In: Ettr, H., Gärtner, G., Gerloff, J., Heynig, H. \& Mollenhauer, D. (Eds): Süsswasserflora von Mitteleuropa 2/4: 1-437, Gustav Fischer Verlag, Stuttgart.

Lange-Bertalot, H. \& Krammer, K. (1989): Achnanthes, eine Monographie der Gattung mit Definition der Gattung Ceceoneis und Nachträgen zu den Naviculaceae. - Bibl. Diatomol. 18: 1-393.

Lange-Bertalot, H. \& Metzeltin, D. (1996): Indicators of oligotrophy - 800 taxa representative of three ecologically distinct laketypes. Carbonate buffered-Oligodystrophic - Weakly buffered soft water. - Iconogr. Diatomol. 2: 1-390.

Monnier, O., Lange-Bertalot, H., Hoffmana, L, \& Ector, L. (2007): The genera Achnanthidium Kütz. and Psammothidium BuKhtiYarova et Round in the family Achnanthidiaceae (Bacillariophyceae): a reappraisal of the differential criteria. Cryptogamie Algol. 28: 141-148.

Monnier, O., Lange-Bertalot, H., Rimet, F., Hoffmann, L. \& Ector, L. (2004): Achnanthidium atomoides sp. nov. a new diatom from the Grand-Duchy of Luxembourg. - Vie Milieu 54: 127-136.

Morales, E. A., Fernández, E. \& Kociolek, P. J. (2009): Epilithic diatoms (Bacillariophyta) from cloud forest and alpine streams in Bolivia, South America 3: diatoms from Sehuencas, Carrasco National Park, Department of Cochabamba. - Acta Bot. Croat. 68: 263-283.

Patrick, R. M. \& Reimer, C. W. (1966): The Diatoms of the United States exclusive of Alaska and Hawaii. Volume 1. Fragilariaceae, Eunotiaceae, Achnanthaceae, Naviculaceae. - Monogr. Acad. Nat. Sci. Philadelphia 13: 1-688.

Ponader, K. C. \& Potapova, M. G. (2007): Diatoms from the genus Achnanthidium in flowing waters of the Appalachian Mountains (North America): Ecology, distribution and taxonomic notes. - Limnologica 37: 227-241.

Potapova, M. (2006): Achnanthidium zhakovschikovii sp. nov. (Bacillariophyta) and related species from rivers of Northwestern Russia. - Nova Hedwigia 82: 399-408.

Potapova, M. \& Hamilton, P. (2007): Morphological and ecological variation within the Achnanthidium minutissimum (Bacillariophyceae) species complex. - J. Phycol. 43: 561-575.

Potapova, M. G. \& Ponader, K. C. (2004): Two common North American diatoms, Achnanthidium rivulare sp. nov. and $A$. deflexum (Reimer) Kingston: morphology, ecology and comparison with related species. - Diatom Res. 19: 33-57. 
Ross, R., Cox, E. J., Karayeva, N. I., Mann, D. G., Paddock, T. B. B., Simonsen, R. \& Sims, P. A. (1979): An amended terminology for the siliceous components of the diatom cell. - Nova Hedwigia Beih. 64: 513-533.

Round, F. E. (2004): pH scaling and diatom distribution. - Diatom 20: 9-12.

Round, F. E. \& Bukhtiyarova, L. (1996): Four new genera based on Achnanthes (Achnanthidium) together with a re-definition of Achnanthidium. - Diatom Res. 11: 345-361.

Round, F. E., Crawford, R. M. \& Mann, D. G. (1990): The Diatoms. Biology \& Morphology of the Genera. - Cambridge University Press, Cambridge, 747 pp.

SPSS InC. (1989-2007): SPSS Professional Statistics 16.0 for Windows, SPSS Inc. Chicago, IL, USA.

SPSS Inc. (2001): SigmaPlot 2001 for Windows version 7.101 (1986-2001). Chicago, IL, USA.

Taylor, J. C., Harding, W. R. \& Archibald, C. G. M. (2007): An Illustrated Guide to Some Common Diatom Species from South Africa. WRC Report TT 282/07.

Van de Vijver, B., Ector, L., Beltrami, M. E., de Haan, M., Falasco, E., Hlúbiková, D., Jarlman, A., Kelly, M., Novais, M. H. \& Wojtal, A. Z. (2011a): A critical analysis of the type material of Achnanthidium lineare W. Smith. - Algological Studies 136: $\mathrm{XXX}-\mathrm{XXX}$

Van de Vijver, B., Jarlman, A., Lange-Bertalot, H., Mertens, A., de Haan, M. \& Ector, L. (2011b): Morphology and ecology of four new European Achnanthidium species (Bacillariophyceae). - Algological Studies 136: xxx-xxx.

Wojtal, A. Z., Lange-Bertalot, H., Nautiyal, R., Verma, J. \& Nautiyal, P. (2010): Achnanthidium chitrakootense spec. nov. from rivers of northern and central India. Pol. Bot. Journ. 55: 55-64.

Zidarova, R., Van de Vijver, B., Mataloni, G., Kopalová, K. \& Nedbalová, L. (2009): Four new freshwater diatom species (Bacillariophyceae) from Antarctica. Cryptogamie Algol. 30: 295-310.

Manuscript received September 30 2010, accepted November 272010.

The authors' addresses:

Maria Helena Novais, Daša Hlúbiková, Lucien Hoffmann \& Luc Ector

Public Research Centre - Gabriel Lippmann

Department of Environment and Agro-Biotechnologies (EVA)

Rue du Brill, 41

L-4422 Belvaux, Luxembourg

E-mails: novais@lippmann.lu,hlubikov@lippmann.lu, hoffmann@lippmann.lu, ector@lippmann.lu

Maria Helena Novais \& Manuela Morais

Laboratório da Água

Universidade de Évora, Parque Industrial e Tecnológico

Rua da Barba Rala n ${ }^{\circ} 1$

P-7005-345 Évora, Portugal

E-mails: hnovais@uevora.pt,mmorais@uevora.pt 